\title{
MAKING A TREATY: THE NORTH AMERICAN EXPERIENCE
}

\author{
Diane Barwick \\ for the Aboriginal Treaty Committee
}

With a Foreword by H.C. Coombs

\begin{abstract}
This contribution includes a paper written by Diane Barwick to aid the discussions of the Treaty Committee established in 1979 to consider the question of a Treaty with Aboriginal people. It is introduced and given context by H.C. Coombs. He chaired that Committee, which included Dymphna Clark, Eva Hancock, Stewart Harris, Hugh Littlewood, Judith Wright McKinney, Charles Rowley, and Bill Stanner.
\end{abstract}

The Editors

\section{FOREWORD}

\section{H.C. Coombs}

In the late 1970s, when the idea of a Treaty with Aborigines began to be seriously discussed by a small group of concemed citizens in Canberra, Diane Barwick was active in the discussions. She declined, however, to become a member of the Treaty Committee when in 1979 action was taken formally to establish it. She felt that it was inappropriate that she, a Canadian citizen, should take an active role in a campaign to influence political events in Australia.

However, when it became apparent that Bill Stanner's health would not permit him to continue as an active member of the Committee, he was most anxious that Diane should take his place. This was not simply because Bill had a profound respect and admiration for Diane's intellectual capacity and her work as an anthropologist. I believe it was also because he had reservations about his role in the Committee and the campaign it was conducting. In a way, to belong to such a body and to sponsor such a program was not the kind of thing Bill would normally have done. It sat ill with the Mandarin aloofness which in his view went with the role of scholar. I think that he was concerned lest without him we would lack anthropological expertise and perhaps the intellectual toughness and political realism necessary if we were to prevent our campaign's deteriorating into sentimentality. I believe he saw Diane's high professional standards, objectivity and independence strengthening the Committee in these respects and regarded her firm Canadian identity and commitment as contributing to these qualities. Under his persuasion Diane acepted membership of the Committee when he resigned. It is likely that she saw herself as a kind of deputy for him.

Diane's paper 'Making a Treaty: the North American experience' would have justified fully expectations of the kind I have attributed to him. It bears the mark of a well-informed critical mind. It contains no advocacy for or against a Treaty for Australians, Aboriginal or non-Aboriginal. Her historical review, however, makes it clear that the law, international or national, at all times lagged behind emerging events, serving to vindicate what had been done: at the international level establishing a framework of international law which made it easier to administer what the great colonising powers could agree upon between themselves 
while at the domestic level protecting the status quo created by the 'first trespasser' who had demonstrated a capacity to maintain his trespass against others.

Certainly, early administrators in Australia during the settlement period acted to legalise the theft which the settlers had committed. So, too, contemporary governments and judicial authorities have validated the actions of mining companies as they pushed out beyond the frontier into the 'waste' lands still occupied and used by Aborigines. Particularly relevant to our present concerns is Diane's insistence that treaties in North America have been instruments of grants of land from the Indians to the United States and Canada rather than the reverse. So indeed would be a Treaty here.

It could, however, set some limits to the areas where the trespassers can still go in confident expectation of their theft's being validated by the law and it could, like the North American treaties, give some compensation for past 'grants' unwillingly made, without negotiation, under the threat or reality of force. Those Australians who seek a Treaty will find much to ponder over in Diane's paper.

A fascinating piece of history of which Diane reminds us is that the Treaty of Waitangi concluded between the British Crown and the Maori people was validated in the Legislative Council of New South Wales, to which, Diane reports, New Zealand had been annexed. The legal implications of that act of the Crown through its New South Wales legislative body for subsequent historical events would make a fascinating study.

It is good that this work of Diane's, originally circulated privately among the Aboriginal Treaty Committee support groups, will now be more widely known. All Australians have good reason to be grateful to Diane Barwick. She has made it possible for us to confer about a Treaty with greater understanding and perhaps therefore with greater chance of success. 


\title{
MAKING A TREATY: THE NORTH AMERICAN EXPERIENCE
}

\author{
Diane Barwick \\ for the Aboriginal Treaty Committee
}

\begin{abstract}
You may be sure that my Government of Canada recognises the importance of full compliance with the spirit and terms of your Treaties.
\end{abstract}

Her Majesty The Queen, to the Indians of Canada, 5 July 1973.

The Aboriginal Treaty Committee, a small group of white Australians who are supported by a growing number of sympathetic sponsors, is asking the Australian government to make a treaty with respresentatives of the Aboriginal and Torres Strait Island people. The committee suggests that a formal agreement could provide protection for Aboriginal identity, languages, law and culture. It could provide a means of recognising and restoring rights to land throughout Australia. It could provide compensation for the loss of land and damage to the territory and traditional way of life of the indigenous people of Australia. It could also provide a guarantee of the rights of Aboriginal Australians to control their own affairs. The terms, and the methods of negotiating such a treaty, are of course a matter for decision by Aborigines. 1

A treaty is 'a settlement arrived at by treating or negotiation' which gives rise to binding obligations between the people who make the agreement. The word treaty covers several ideas: a contract, a kind of legislation, and international law. Today the definition of treaty used by the United Nations is 'an international agreement concluded between States in written form and governed by international law'. But the British government for several centuries made treaties with tribal groups, at first as independent powers and later as subject 'domestic nations'. There are also modern examples of treaties made between states and their own subjects: the Irish Free State Treaty of 1921 was an agreement made by the British government with an ethnic minority in its dominions; in the Lateran Treaty of 1929 the King of Italy recognised the independence and sovereignty of his subjcts the Pope and the Holy See. ${ }^{2}$ There are also modern examples of formal agreements concerning reparations or compensation for invasion and war damages.

There is much historical and legal evidence that the North American Indian treaties were not international treaties in the sense of agreements between independent and sovereign nations. The English claimed sovereignty even when the Indians retained military

1 This paper tries to summarise the large literature on land claims and treaties in North America, and particularly in Canada. The most important recent sources are listed in the bibliography. I gratefully acknowledge the help of Professor Sally Weaver of the University of Waterloo and Dr John Leslie, Chief, Treaties and Historical Research Centre, Department of Indian and Northern Affairs, in providing up-to-date documentation on the situation in Canada. The views expressed in this paper are my own, and do not necessarily represent the opinions of the Aboriginal Treaty Committee.

Green 1970:114-5. 


\section{ABORIGINAL HISTORY 1988 12:1}

independence, and in the later Canadian treaties both government and Indian negotiators clearly considered the Indian peoples to be subjects of the Queen. But more or less clearly expressed in the treaty documents is the idea that the Indians 'constituted separate and sovereign peoples subject to their own law, who were capable as nations and tribes of forming and breaking alliances with colonial powers, and who had national or tribal territories under their control', 3

\section{Why a treaty?}

In Australia the British government did not recognise the property rights of the inhabitants as it did in other colonies. Aborigines have complained about - and resisted - the taking of their land ever since 1788. But it was not until 1971 that they asked a court to judge their claim that they had been 'invaded unlawfully. ${ }^{4} \mathrm{Mr}$ Justice Blackburn examined the legal and historical evidence carefully, but concluded that the doctrine of 'comunal native title' had never been given judicial, legislative, or executive recognition in Australia. He also examined the Aborigines' evidence about their system of land holding, but decided they did not have a proprietary interest under the ordinary principles of property law. Criticisms of this decision ${ }^{5}$ were mentioned in one judge's opinion on a later generalised Aboriginal claim dismissed by the High Court of Australia in April 1979.6 But both courts found binding an 1889 ruling by the Judicial Committee of the Privy Council that this continent was not acquired by conquest or cession; rather it was 'practically unoccupied, without settled inhabitants or settled law at the time it was peacefully annexed'.

The courts are bound by the laws and judgments of the past. It does not seem that they can help Aborigines and other Australians in making the just settlement of land claims that is needed for the future.

The Aborigines are not alone in asking for a just settlement of their historic grievances. In the 1970s North American Indians and Maoris asked their national governments to make new kinds of formal agreements which acknowledge their prior ownership and provide guaranteed rights of self-government and greater recognition of their historic identity and culture.

The objectives of Canadian Indians are well described by the Indian Claims Commissioner. Indians continue to resist pressures for assimilation. They insist they have 'an inherent right to a special status as a nation within a nation'. The government has accepted his finding that their claims must be settled justly, as a matter of right:

They have given up much in this country, and they feel that the assistance

they receive from Government must be seen as a right in recognition of this

loss and not merely as a handout because they are destitute. ${ }^{7}$

The American Indian Policy Review Commission set up by the United States Congress examined the same issues of history and morality in its final report. This 1977 document argued that the question is not merely one of restitution for past wrongs, but whether the American nation can redirect and renegotiate its relations with Indians who wish to retain their cultural, religious and tribal sovereignty.

Smith 1975:xv; Cumming and Mickenberg 1972:53-61.

4 Milirrpum and Others v. Nabalco Pty Ltd and the Commonwealth of Australia; 17 Federal Law Reports 141.

5 Hookey 1972; Lester and Parker 1973.

6 Coe v. Commonwealth of Australia, 24 Australian Law Reports 118.

7 Barber 1974:13-14. 


\section{MAKING A TREATY}

Aboriginal claims are also defined in moral terms, on the basis of right, not merely on need. The moral principle was clearly stated in 1972 by W.E.H. Stanner when pointing out that no declaration of policy by any Australian government has ever included two necessary admissions:

The first is that we injured Aboriginal society and owe just recompense to its living members. The second is that what we will now do for them we will do in recognition of their natural rights as a distinct people, not in expression of our sufferance of them, or of our acceptance of them if they will copy our ways. I think these words, if said in the Parliament of the Commonwealth, on behalf of the whole nation, might make a difference. ${ }^{8}$

The same distinction was made by Senator Neville Bonner in his Senate speech of 19 September 1974 calling for 'true and due entitlement for dispossession', not merely the giving of money for a disadvantaged people as a form of charity. His motion urging the Commonwealth government to 'admit prior ownership' and legislate to provide compensation was unanimously passed by the Senate on 20 February 1975.9

During the 1960s many citizens and government spokesmen in Canada, the United States, Australia and New Zealand argued that land claims were not relevant in today's world. They said the claims of native ${ }^{10}$ people could not be recognised because special rights would destroy national unity. They said all citizens should be equal. They could see that native people had economic, social and educational problems, but argued that these could be solved by special welfare programs.

Many Australians still believe that justice for Aborigines is best achieved by intensive government programs aimed at bringing about equality with other citizens. Many of them still argue that expanding government welfare, health care and employment programs is the only realistic form of compensation for past injustice to Aborigines. This ignores two important questions, as the chairman of the Treaty Committee has pointed: the adequacy of this compensation, and the right of Aborigines to establish their own institutions to control and administer it. 11

Indians, Maoris and Aborigines do not want govemment charity. To them the suggested remedies seem just a more sophisticated version of the older paternalistic policy of assimilation.

Since the Second World War many former colonies have gained independence. Often they are described as 'Third World' countries. A Canadian Indian spokesman who travelled to Australia, New Zealand and the United States to study the problems of other native minorities found that the people of these former British colonies had much in common. He has described the 'domestic nations' of native people in these countries as 'the Fourth World'. Indians, Maoris and Aborigines cannot hope for independence and complete control of their lands because their colonial rulers will never go home. They can only hope for recognition of their moral claim to a special status based on their prior occupation of these lands, and work for greater political and economic self-determination.

George Manuel points out that the Fourth World people ask for no more than the 'home rule and responsible government' that the European colonists long ago obtained from

8 'After the Dreaming - whither?' Address to the Royal Australasian College of Surgeons, 28 October 1972. In Stanner 1979:337-8.

9 Harris 1979.

10 The word 'native' is the name preferred by North American 'Indians' and has been used throughout this paper to mean the original inhabitants of a territory.

11 Coombs 1979a:4. 


\section{ABORIGINAL HISTORY 1988 12:1}

the British government. He argues that economic development without full local control is simply a new form of conquest. He explains why they do not welcome development schemes that promise them only an uncertain number of menial jobs - and an unpredictable amount of pollution - in return for the certain destruction of their homelands. ${ }^{12}$

This Canadian Indian spokesman points out that the Fourth World peoples resent being told that their culture is 'lost' or 'dying', and that their separate identity is merely the result of poverty and oppression. Such arguments seem silly: 'Do they think that if they stop the oppression we will stop being our parents' children?' The people of the Fourth World resent being told that they must 'forget the past' and seek equality as ordinary citizens. He stresses the continuity of indigenous cultures, and the importance of their territorial base. For Indians (and Maoris and Aborigines), he argues, culture and identity is 'every inch of our land and every event of our history'.

All the cultures of the world blend the old and the new. The 'traditional' cultures of Fourth World peoples survive today because they have been capable of reconciling past adaptations with recent innovations. Indian and Maori and Aboriginal people have selected and reinterpreted ideas and practices from European culture and made them their own. In the same way Europeans have accepted new ideas to serve changing needs. Today few Fourth World people willingly give up their cultural heritage and their community ties to become completely assimilated as 'ordinary' citizens. Most still feel that their attachment to family and familiar territory is a precious source of security and strength.

In the 1970s the Fourth World communities are everywhere forcing their fellow citizens to think again about land use and the future. They have challenged government plans for development, pointing out that the 'frontier' is also a homeland. They ask other citizens to think carefully about the future of our children's children and our present use of natural resources. 13

\section{Native land rights and English law.}

Our schoolbooks say that Europeans first 'discovered' North America in 1492. Spain claimed title to the new-found lands. But English sovereigns disputed this, and authorised their own seamen to claim any lands they were able to 'subdue, occupy and possess' by conquering the inhabitants. Up to 1722 English legal opinion argued that the king could acquire possessions only by inheritance or conquest - and obviously the Crown title to the newly-discovered overseas lands was a title by conquest. In the sixteenth century English writers joked about the absurdity of gaining possession of a continent by sailing along its coastline or landing a small party to explore some portion of it. ${ }^{14}$ It was a hundred years before arguments that 'discovery' was sufficient reason for a claim to ownership of unknown lands were taken seriously. But in the 1600 s the doctrine that overseas possessions could be acquired by discovery and settlement gained strength in English law. It was confirmed in a 1722 Privy Council decision that 'new found country is to be governed by the laws of England'. English legal theory held that colonies could not be established if the Crown refused to accept sovereignty (this nearly happened in New Zealand). The Crown could also decide what status a colony should have: whether the territory was 'occupied' and needed to be conquered or was 'waste and uncultivated' and therefore simply needed to be discovered and

\footnotetext{
12 Manuel and Posluns 1974:150, 182.

13 Berger 1977; Watkins 1977.

14 Washburn 1959:15-18.
} 


\section{MAKTNG A TREATY}

settled. ${ }^{15}$ But the development of this legal doctrine had little effect on British practice in North America. Expediency encouraged the British to continue recognising the property rights of the Indians, few of whom were agriculturists. Britain still had to compete with Spain for Indian favour, and the tribes would not accept British protection on less favourable terms. In the beginning political necessity forced the British to recognise native land rights in North America; but British sentiments about national honour and the sanctity of the pledged word later prevented them from abandoning these principles and the treaties and legislation based on them. 16

By the time the British wanted to settle Australia the idea that colonies could be obtained by discovery and settlement was 'received law'. The 1765 opinions of the English jurist Blackstone have continued to be upheld in Australian courts. His book on the laws of England was well known to early Australian colonists. Many of them carried it on their journeys of exploration, rather than the Bible, as it offered more guidance about property dealings.

Legal opinions about the justice of English expansion into inhabited territories grew out of beliefs that the 'heathen' had no right to maintain their laws and way of life, and the roaming hunters had 'less right to the land than hard-working farmers'. Arguments that the possession of land by the original inhabitants was standing in the way of progress and civilisation had great appeal for ambitious colonisers. In the eighteenth and nineteenth centuries such arguments were used to justify taking land from native people without compensation. They also justified assuming authoritarian control over their lives instead of recognising their right to self-determination. 17

But these English legal arguments ignored the established principles of international law. When the New World was first discovered, Europeans debated whether the inhabitants were humans or beasts of the forest. In 1537 the Pope pronounced that these 'Indians, and all other people who may later be discovered by Christians, are by no means to be deprived of their liberty or the possession of their property'. These were human rights to which all, including non-Christians, were entitled. In 1532 Vitoria, a Spanish church lawyer, had spelled out these rights: the original inhabitants were everywhere entitled to retain the land they occupied, which would not be taken from them except in a 'just' war or by negotiated purchase. The Indians were 'true owners' of the lands they possessed and the idea of 'title by discovery' had no force in inhabited lands. ${ }^{18}$ Thus for more than four hundred years the lawyers and statesmen of Europe have been aware that the taking of land and other property from the native people of their colonies without compensation, or with ridiculously inadequate compensation, was a moral offence and was 'contrary to the main currents both of international and common law'.19

For several centuries legal theorists have tried to justify English expansion into inhabited territories. The title of the sovereign (in English law) obviously conflicted with the natural rights or original title of the native people in possession. English common law had long ago accepted the rule of international law that 'a change of sovereignty does not affect existing private rights'. 20 Another accepted convention of international law was that

Lester and Parker 1973:197-200.

16 Cohen 1960a:250-51.

17 McNickle 1976:55.

18 Cohen 1960a:239-43; 1960c:290.

19 McConnell 1973-74:121.

20 Hookey 1972:88-9.
} 
the first 'discovery' gave title against other European powers - which meant that English explorers planted their flags fairly hastily, to keep out competitors. The problems of legal theory grew even more difficult as settlement overran 'not only what European thinkers considered the natural rights of the Indian but those rights guaranteed by solemn treaty'.21 If courts did not uphold the pretension that discovery gave exclusive rights to those who made it, then all real estate titles in British colonies would be invalid.

All modern judgments and commentaries on 'aboriginal title' refer to an 1823 judgment of the United States Supreme Court, which declared that native title was limited by the sovereign's 'title by discovery'. The legal commentators do not discuss the political pressures Chief Justice Marshall was under. The historian Washburn points out that Marshall had to consider expediency as well as law, for a judgment favourable to the Indians would have meant that the President (an old 'Indian-hunter') refused to enforce Supreme Court orders:

On his decision hinged the title to the real estate of the nation, the independence of numerous Indian nations, the sanctity of treaty rights, and even the very existence of law and order. 22

He upheld the ancient property rights of Indians, but said they could be extinguished by the European colonisers, who held ultimate title by the 'right of discovery'. Washburn suggests that this legal doctrine might be better described as the 'pre-eminent right of the first trespasser'.

The first 'trespasser' in Australia was Captain Cook. He had been instructed to take possession of this land 'with the consent of the natives'. But he claimed possession of the east coast of the continent in 1770 after only a few days' observation of the Aborigines. Knowing nothing of their land tenure system, he decided they 'move about like wild Beasts in search of food' and reported that 'we never saw one Inch of cultivated land in the whole Country'. It was easy to decide that this continent was 'waste and uncultivated' and could be settled without recognising and paying compensation for Aboriginal land rights. The British government now needed new territory because the American revolution had ended their control of half of North America (and most of the rest was still in Indian possession). Fromn 1786 to 1825 the instructions given to the colonial governors made no mention of Aboriginal land rights, and then only urged Governor Darling to protect them 'in the free enjoyment of their possessions'. It was not until the colony of South Australia was established that a governor was required to recognise Aboriginal rights to occupy their lands - and this instruction was soon cancelled.

The British government never ordered Australian officials to make inquiries about Aboriginal ownership of land, or to purchase land from them for settlement. Captain Cook's 'discovery' and the presence of settlers justified British claims to sovereignty. When a group of Tasmanian land speculators made a private 'treaty' in 1835 with certain leaders of Woiwurrung and Bunurong clans who owned the territory around Melbourne, the colonial governor quickly proclaimed that this was simply 'trespass'. The treaty embarrassed the government. It showed that the land was occupied and treaties were negotiable. If it was lawful it would undermine all the land titles and transactions authorised by the government. The treaty was considered a fraud by the businessmen who made it. The clan headmen who signed it would not - and could not - have sold their land. But they obviously understood it as a contract of 'peace and friendship'. Four of them, responsible for the lands the settlers now occupied, gave warning of the massacre planned by more distant clans in October 1835 . 


\section{MAKING A TREATY}

And throughout the 1840 s they complained to their government protectors that the Europeans had treacherously betrayed this solemn agreement.

So well-established was the British practice of making treaties to purchase land for settlement that an 1837 report of a Select Committee of the House of Commons expressed astonishment that the government had completely ignored the claims of the Australian Aborigines as 'sovereigns or proprietors of the soil' and had taken their land from them 'without the assertion of any other title that that of force'. These members of Parliament questioned the government's 'oversight'. But the government's neglect continued to be excused by arguments that the Aborigines lacked any recognisable system of political organisation and customary land tenure. The British government's failure to make treaties in Australia began to look even more peculiar when it made a treaty with the Maoris in $\mathbf{1 8 4 0}$ and then 'annexed' this colony to New South Wales.

By the Treaty of Waitangi the Maoris were guaranteed 'full, exclusive and undisturbed possession of their properties' subject only to the Crown's right of pre-emptive purchase. The British gained title by 'cession' (the giving up of Maori title) - and to make sure proclaimed title over the whole area by right of 'discovery'. When the British government decided in 1848 to alter its policy on Maori property rights despite the guarantees given in the treaty, the Chief Justice of New Zealand upheld the sacredness of the treaty obligations. He argued that the intended policy was 'colonisation by seizure' and insisted that abandoning the 'old national principle of Colonization by fair purchase' was a violation of 'established law'. He said Britain had an obligation to honour its promises as a ;'matter of national faith'. The British government decided to abide by the treaty guarantees. ${ }^{23}$

Unfortunately subsequent local governments were less scrupulous about alienating Maori lands. For more than a century Maoris have protested against the consequences of government policies which demanded their assimilation - and their land. The Treaty of Waitangi remained a kind of Maori 'Magna Carta', and its importance was upheld by the 1975 Treaty of Waitangi Act establishing a tribunal to investigate all Maori claims that government legislation, policy or practice has been harmful and inconsistent with the principles of the treaty. 24

\section{Native claims and treaties in North America.}

The North American experience, and particularly that of Canada, has some relevance for Australians interested in the settlement of land claims. This is not just because the legal systems of Canada and Australia are derived from English law. Both countries must reconcile the interests of federal and state or provincial governments when settling native claims (although the Canadian federal government has had exclusive rights of guardianship or trusteeship over Indians since 1867). Both countries are subject to international pressure to develop non-renewable natural resources in their northem territories - lands which have remained in native possession until recently.

In Canada and Australia the original inhabitants had land tenure systems very different from the feudal agricultural system on which English property law was based. Most of the tribes of Canada were hunters and gatherers. Their economic use of land, the flexible recruitment of land-using groups and their lack of centralised political authority were in many ways similar to the social organisation of Australian Aborigines.

Yet the original title of Indians was recognised by the British. The title of the Aborigines has been ignored.

23 Lester and Parker 1973:214-8.

24 Metge 1975:330-31; Kawharu 1977; King 1975. 


\section{ABORIGINAL HISTORY 1988 12:1}

The Bibliography following this paper lists many discussions by legal experts of the concept of 'aboriginal rights' or 'communal native title'. The concept, which has never been defined in Canadian, British or international law, is generally taken to mean the property rights or title which native people retain as a result of their original use and occupancy of land. They have rights because of their occupation of certain lands 'from time immemorial'. An 'aboriginal title' can be interpreted as 'the nomadic range rights of an identifiable nomadic group over a wide but definable area for food-gathering . . . where it can be shown that this territorial imperative is maintained by force of arms, agreement or lack of serious competition, and this way of life can quite legitimately be referred to as 'ancient' or 'traditional'.25

Many legal experts argue that British, Canadian and American law has always recognised 'aboriginal rights'. The legal theory originated in the sixteenth century as part of international law. The basic idea is that the inhabitants retained their property rights when European nations claimed sovereignty of their territories, and these rights remained a burden on the newcomers' title until formally 'extinguished'. These rights could only be surrendered to the Crown (the European government claiming sovereignty). The Crown could extinguish communal native title by conquest - the old idea of expropriation after a 'just' war - or by purchase.

British recognition of native title in North America was deliberately confirmed by Royal Proclamation in 1763. All lands in Indian possession (a vast area of North America) were to be retained for their own use. No land could be taken from them for European settlement until Indian title had been cleared by Crown purchase. This required negotiation and the signing of treaties. Crown participation was intended to ensure that the Indians received fair treatment (unlikely in private dealings with settlers). Of course this was also intended to protect the Crown's right under English law to grant real estate titles and profit from land sales.

As long as the British were in control in North America they did not dispossess Indians of their land without purchase. The Proclamation still has the force of a statute in Canadian law. Legal experts insist that the Proclamation did not create 'aboriginal title': it merely confirmed aboriginal rights which had their source 'in the law of nations, now incorporated into the common law'.26

Before this time most of the land acquired by English settlers had in fact been purchased from Indians. But the formal 'treaties' between Indians and British officials were mainly intended to secure peaceful relations between Indians and colonists, or to gain Indian allies against other would-be colonisers. British officials were first instructed to make 'peace and friendship' treaties in 1670 .

After 1763 the treaties were basically land surrenders. Purchase, not conquest, was the British govemment's only legal means of acquiring land in advance of settlement, to prevent the warfare that had occurred in the United States. In the post-1867 Canadian treaties the Indians agreed to 'cede' (give up) all rights to described territories, in return for annual payments, smaller reserved areas, and special hunting and fishing rights over the land given up, was well as any special privileges detailed in a particular treaty. About half of the Indians of Canada were covered in the sixty-seven treaties made between 1725 and 1929.27 But in the far north, where there was until recently no pressure for development, and in the 


\section{MAKING A TREATY}

westernmost province, where land-hungry settlers insisted treaties were not necessary, the federal government did not obtain surrenders of the Indians' 'aboriginal title'.

After the United States gained independence from Britain there had been much debate about the land title question. Many settlers argued that it could be settled most effectively by exterminating the Indians. Fortunately, the military administration responsible for Indian affairs argued that this would be not only dishonourable but too expensive. It cost two million dollars a year to maintain a regiment on the Plains in 1865 , and the Indians there were elusive targets. In the last years of the Indian wars 'it cost the United States on an average four million dollars to kill an Indian'. So treaty-making continued until all had been removed to reservations. ${ }^{28}$

The American government had higher standards than its citizens: its first major law passed in 1787 declared that the land and property of Indians would 'never be taken from them without their consent' and they would never be invaded or disturbed 'unless in just and lawful wars authorised by Congress'. For eighty-five years the United States maintained a policy of extinguishing native title by negotiating treaty purchases. Two million square miles, 90 per cent of United States territory, were purchased under 372 treaties, at a cost of eight hundred million dollars in cash and services. ${ }^{29}$ But in 1871 the govemment passed a law declaring that Indians would no longer be recognised as independent tribes, nations or powers capable or making treaties. Afterwards they were considered to be federal wards, but tribes retained a degree of sovereignty and rights of self-government on their lands. These rights were first confirmed by the courts in 1832, when Chief Justice Marshall declared that Indian tribes had always been considered 'independent political communities retaining their original natural rights' and the accepted rule of international law applied: 'a weaker power does not surrender its independence - its right to self-government - by associating with a stronger, and taking its protection' 30

The North American treaties were all formal written agreements, signed at public meetings of the tribes after extended negotiation with colonial governors or other senior representatives of the Crown. The government wanted peace as much as it wanted land, and this discouraged deliberate fraud, for dissatisfied Indians could endanger and put an end to settlers' occupation of the ceded lands. But there was certainly misunderstanding: few Indians could have foreseen the real consequences of giving up their land. The treaties were made with great solemnity, and both parties spoke of the necessity for honour and good faith in maintaining treaty promises. A 1961 volume on The law of treaties says of these agreements:

Everything we know about the Indians and the treaties suggests they were understood by the tribes, as they have consistently been by their descendants, as constituting legal arrangements binding upon the Crown for all time. ${ }^{31}$

The treaties have consistently been upheld by Canadian and American courts as obligations enforceable at law. Treaty provisions prevail over provincial and state laws, and can only be overruled by laws passed by the federal governments. ${ }^{32}$

Overall, the treaties have been considered morally and legally binding agreements by the governments of Canada and the United States. But some treaty promises were broken by

28 McNickle 1976:255; Hagan 1976:159; Cohen 1960b:269.

29 Cohen 1960c:279-88.

30 Cohen 1960a:234.

31 Cited in Green 1970:125.

32 Cumming and Mickenberg 1972; Cohen 1960c. 
nineteenth and twentieth century administrators. And, as Indians now point out, there was always some coercion in making land surrender treaties. Indians had to give up the land wanted for settlement. They could only bargain with the government negotiators for the best possible terms. Yet the treaties are still important to Canadian Indians. The treaties represent a recognition of their historic identity and an acknowledgment of their prior ownership. Indians fiercely resisted the Canadian Prime Minister's 1969 argument that the treaty relationship was outdated and should be ended. ${ }^{33}$

\section{The settlement of land claims today.}

Four methods of settling native claims have been used in North America. Indians have found that litigation in the courts is the least satisfactory. It is slow, expensive and full of technical difficulties, since decisions must rest on legal definitions and case law drawn from European legal history, ill-suited to dealing with the land tenure systems of hunters and gatherers. But Indians have found that taking legal action can be a useful method of forcing governments to change laws and policy: only very insensitive political leaders will ignore grievances that the courts uphold. ${ }^{34}$

Settlement by an administrative tribunal has been important in the United States. Since 1946 the Indian Claims Commission has considered hundreds of cases brought by Indian groups who claimed they had been unjustly treated by the government. Money compensation is paid for land losses and as damages for unfair and dishonourable dealings by the United States, but alienated land is not restored to tribal ownership. ${ }^{35}$

The third method of settling Indian claims has been legislative settlement - laws passed by government. The justice of such settlements depends upon the power relations between government and native minority, but they provide a rapid political solution when native claims delay resource development. Following a 1959 court decision that native title had never been extinguished, and a 'land freeze' preventing disposal of land subject to native claims (90 per cent of Alaska), the American government passed the 1971 Alaska Native Claims Settlement Act. As compensation for giving up their title, the native people received forty million acres of land (11 per cent of the state) plus cash compensation and royalties totalling US\$962.5 million, to be controlled by native-managed development corporations. The Act was intended to enable the natives to participate in Alaskan life on the same basis as other citizens. Their traditional style of life is not protected, and various land and tax provisions may cause them great difficulty in future. ${ }^{36}$

A fourth model, negotiated settlement, has been used in Canada. Governments and native groups have bargained for agreements politically acceptable to both sides. It is in a sense a continuation of the treaty-making process, but the Canadian government and its Indian subjects still have unequal powers and somewhat different goals. Aboriginal title has never been extinguished in the north of Canada, where there is now much pressure for development of natural resources. But the native people will no longer settle for total extinguishment of their rights. The north is their homeland and they wish to preserve their way of life for their children's children. ${ }^{37}$ Negotiators have concluded that a just settlement

35 Lurie 1957; Lysyk 1972; Witt 1968; Wilkinson 1966-67.

36 Hunt 1978.

37 Berger 1977. 


\section{MAKING A TREATY}

is only possible if other Canadians recognise that the native claims rest on 'spiritual and cultural bases which are simply not negotiable'. 38

In 1969 the Canadian government proposed a new policy for Indian welfare, arguing that the termination of all special legislation was a prerequisite for the achievement of Indian equality. Within months the Prime Minister admitted that he had been wrong in thinking 'that equality meant the same law for everybody'. Pressure from outraged Indians, Parliament and public forced a formal withdrawal in 1971.

An Indian Claims Commissioner was appointed to examine specific claims and grievances in 1969; his mandate was expanded to include all 'aboriginal title claims' in 1971. In 1973 the government announced that it would negotiate settlements of all 'comprehensive claims', covering every area where aboriginal title had not been extinguished. In 1970 the government began to fund native associations to conduct their own research on historic rights and grievances and to prepare land claims for submission to the cabinet. The situation was complicated by historic differences between 'status' and 'nonstatus' Indians (who do or do not come under the Indian Act, and only some of whom are 'treaty' Indians), and the Métis (people of Indian descent excluded from earlier treaties, whose claims were dealt with instead by payments of land or cash), and Indian groups who settled in Canada following the American Revolution, who have no 'aboriginal title' because they are immigrants. There are also the Inuit (Eskimo) people, who have never been asked to sign land surrender treaties.

By early 1979 the government had given their various associations almost Can\$16 million for claims research plus another Can $\$ 23$ million as loans to groups negotiating accepted claims. ${ }^{39}$ A 'Treaties and Historical Research Centre' provides expert assistance and access to records in government archives. A separate Office of Native Claims handles the government's negotiating tasks.

As well as funds for claims negotiation the government has, since 1970 , provided massive funding for native political associations at local, regional and national levels. This has done much to overcome the long-standing isolation caused by poverty and cultural and language differences, but co-ordination of native associations is difficult because the 'grassroots' communities have very different problems, interests and priorities. Without this special funding native people would not be able to prepare claims or have the structures to negotiate them. 40

During the 1970s the Canadian government pledged itself to involve native people in decision-making at every level, right up to the federal Cabinet. Joint participation has given native leaders and government representatives a new acquaintance with each other's views, and perhaps a greater sense of responsibility and accountability to the people for whom they make decisions. But progress is slow and trust is fragile. From 1975 until the Indians withdrew in 1978 a joint Cabinet-National Indian Brotherhood Committee negotiated directly on all issues affecting Indian people. This collapse caused the disbanding of the Canadian Indian Rights Commission established to aid the joint committee's work on deciding settlement mechanisms. Another joint Cabinet committee involves the national Metis association. The government announced in 1971 that policy changes must come from

38 Naysmith 1977.

39 Daniel 1980.

40 Weaver 1980; Frideres 1974. 


\section{ABORIGINAL HISTORY 1988 12:1}

Indian initiatives; these recent changes mean that the future of claims negotiation remains to be decided. 41

Most of northern Canada is still under 'territorial' government and there the federal government has more authority than is the case in the provinces - originally separate colonies like the Australian states - which control land, natural resources and such services as education, but have no responsibility for Indian affairs.

Since 1969 certain treaty grievances have been settled by negotiation but some claims (both specific and comprehensive) are more complicated. These involve lands and resources under the jurisdiction of the provincial governments, which must also participate before a final settlement is reached. These governments have always defended the interests of their large European population in discussions of Indian rights. Indian distrust of provincial intentions was a major reason for objecting to the federal government's 1969 proposal to hand over welfare functions to the provinces and abandon its traditional role as protector. Several provinces have shown considerable interest in remedying treaty injustices, but little progress has been made in negotiating aboriginal title claims in British Columbia, Labrador and Quebec. 42

The first modern land settlement 'treaty' was the 1975 'James Bay and Northern Quebec Agreement'. In 1971 the Quebec provincial government planned an enormous hydro-electric scheme. Planned dams threatened the economic subsistence of Inuit (Eskimo) communities and bands of Cree and Naskapis Indians. They outnumbered the European population in this area and had never signed treaties surrendering their land. Their rights were ignored, but they sought a court injunction halting development until their claims were settled. Sympathisers helped the Cree and Inuit in their campaign to force the provincial and federal governments to acknowledge their rights. Negotiations were extremely difficult. ${ }^{43}$ Finally the Agreement was approved by both Parliaments in the James Bay and Northern Quebec Native Claims Settlement Act of 1977.

This is the most comprehensive Canadian treaty, covering such matters as education, health, royalties, resource planning and so on. The Agreement was much more than a land surrender. It was intended to provide a basis for Indian and Inuit economic development and to safeguard their historic culture. But there has been much controversy about this first treaty of recent times. Many feel it was a 'rip-off'. The protection given for political equality and subsistence and development needs may not be adequate. 44

After two years of negotiation the Naskapis band of the same region signed the 'Northeastern Quebec Agreement' (providing similar benefits for the surrender of title) in January 1978.

\section{'Northern development' and native claims in Canada.}

The native people of the Northwest Territories still outnumber the immigrant European population. Their traditional economic use of this vast area has recently been threatened by southern plans for development of non-renewable resources.

Plans to develop an oil and gas pipeline in the Mackenzie Valley of the Northwest Territories during the 1970 s roused great concern. The Berger Commission report - issued within a few days of the Fox Commission report in Australia - concluded that the project

41 Weaver 1980; Daniel 1980.

42 Danie1 1980; Canada Indian Claims Commmission 1975.

43 Richardson 1975.

44 LaRusic et al. 1979; Hunt 1978. 


\section{MAKING A TREATY}

should not proceed, because it would endanger a fragile environment and have a disastrous impact on the native people. Justice Berger advised the government that the settlement of native claims must precede any development. ${ }^{45}$ The government has decided to build the pipeline elsewhere, and negotiation of native claims is underway. The sophisticated 'Nunavut' and 'Dene' claims demand real protection for the continuity of native societies, but no settlement has yet been reached. The political realities of the native communities and the federal government are so opposed that compromise is difficult.

\section{The ITC 'Nunavut' Claims.}

Early in the 1970s the Inuit Tapirisat of Canada (Eskimo Brotherhood) was established as a political organisation to represent all Eskimo people. Federal funding for three years of intensive land claims research resulted in a three-volume land-use study proving the reliance of the Inuit on almost the whole 750,000 square miles of land. The ITC employed a lawyer, Peter Cumming, to help them draft a comprehensive land claim, presented to the federal Cabinet in February 1976. They asked for outright ownership of 250,000 square miles and harvest rights and 3 per cent royalties on non-renewable resources from another half million square miles. The whole northernmost area of both Territories would become a new territory, Nunavut' (our land), governed by Inuit. 46 But the ITC had meanwhile lost touch with 'grass-roots' communities, and after some political instability withdrew this claim.

A new claim proposal on behalf of the Inuit of the central and eastern Arctic was presented in 1977. Again, the claim called for political self-determination (by means of a Nunavut government within the Canadian confederation, based on Inuit political institutions); ownership of traditional areas (including sub-surface rights); and detailed provisions for protection of Inuit culture, language and the traditional economy. They asked for amendment of the British North America Act (the Canadian constitution) to provide for 'the constitutional recognition and continued assurance of the right of the Inuit to exist as an independent culture within Canada'. The federal government negotiated through 1978 and 1979 but changes in the ITC executive (and a change of government) delayed decisions. At the end of 1979 the ITC was reviewing its claim proposal and announced new negotiating structures. No final agreement-in-principle has been prepared.

\section{The COPE 'Inuvialuit Nunangat' claim.}

When the ITC stopped progress on its 1976 claim, the Committee for Original People's Entitlement submitted a separate claim on behalf of the 2,500 Inuvialuit who had traditional title over 168,000 square miles of the western Arctic. This 1977 claim did not seek special political status, and their participation in new forms of decentralised government is being examined in the separate inquiry on constitutional development of the Northwest Territories which is now underway.

In October 1978, after months of meetings and the circulation of joint position papers, COPE and the federal government signed a 180-page Inuvialuit Land Rights Settlement Agreement-in-Principle'. The Inuvialuit will receive surface and subsurface rights to 37,000 square miles of land plus harvest rights throughout the western Arctic. Participation in a land-use planning commission will give them a major say in the management of land and wildlife. Cash compensation of Can $\$ 45$ million for their surrendered title, plus further funds to develop new businesses, will be controlled by native-owned corporations. Native people will also control the management of a 5,000 square mile wilderness park in this area. The

\footnotetext{
45

46 Berger 1977

Inuit Tapirisat of Canada 1975, 1976.
} 


\section{ABORIGINAL HISTORY 1988 12:1}

government will provide Can $\$ 3.5$ million for a social development program, to be managed by Inuvialuit, which will develop special education programs and other projects for the preservation of their language and culture.

But with a change of government in May 1979 negotiations ceased for review, and apparently there has been little further action on this Agreement since the Liberal government retumed to office.

The Dene and Métis Mackenzie Valley claims.

The Indians of the Mackenzie Valley have special negotiating problems because of the historic differences in the recognised rights of the 'status' Indians, some of whom had signed treaties in 1899 and 1921, the 'non-status' Indians, and the Métis. The threat of pipeline development brought a new unity to the native people, who resented these imposed distinctions and insisted that 'the definition of the Dene is the right of the Dene'. A single settlement is essential for these people, who live together in various communities.

The 7,000 'treaty' Indians of the western region insist that they did not legally or effectively surrender their title when they signed the treaties. ${ }^{47}$ In 1973 they tried to file a 'caveat' with the Land Titles Office covering the lands they traditionally used and occupied a third of the Northwest Territories. The caveat would make future titles subject to existing rights. Their filing was contested and the Territorial Supreme Court made a ruling that the caveat should stand, after months of hearings in native communities. The judgment was successfully appealed by the federal government in 1975 but meanwhile there was a kind of 'land freeze'. 48

The Indian Brotherhood of the Northwest Territories (also called The Dene Nation) and the Métis Association met together in 1974 to plan a single land claim. In 1975 they jointly approved the 'Dene Declaration' and 'Manifesto', demanding recognition of a Dene 'nation', an exclusive homeland and government to be recognised by the governments of the world.

The Canadian government, which of course recalled the nineteenth-century 'Riel Rebellion' (when Métis and Indians proclaimed a separate government and territory which divided Canada in half), and was currently confronting separatist demands by Quebec which also threatened confederation, rejected the concept of a separate nation.

The Métis Association withdrew from joint negotiation in 1976, saying they could not support the 'nation' concept, and obtained funding to prepare a separate claim. Both groups were told there could be only one final settlement. The Dene submitted their claim in October 1976. It argued that:

The Dene, as aboriginal people, have the right to retain ownership of so much of their traditional lands, and under such terms, as to ensure their independence and self-reliance, traditionally, economically and socially, and the maintenance of whatever other rights they have...

There will therefore be within Confederation, a Dene Government with jurisdiction over a geographical area and over subject matters now within the jurisdiction of either the Government of Canada or the Government of the Northwest Territories. 49 


\section{MAKING A TREATY}

The Dene claim, and other statements, ${ }^{50}$ expressed a sophisticated philosophy about the consequences of colonialism and argued that it was necessary to develop a new economic and political structure for native people. But the notion of exclusive control alarmed other citizens. Just before the Métis Association submitted its claim in September 1977 the government appointed a representative to conduct an inquiry on constitutional development which would hear the views of all Northwest Territories residents.

The overlapping Dene and Métis claims had to be jointly negotiated. But no progress was made during 1978 , despite sympathetic approaches by the responsible minister. Pointing out that 'Dene and Métis people are not being asked to sell land', his negotiator urged the two associations to focus on reconciling their claims. Political structures could not be determined by the claims, for the rights of other citizens were involved. In September 1978 the minister announced that further funding for claims negotiation would be suspended until the two associations settled their differences. Already Can $\$ 3.5$ million had been provided in grants and loans. No final claim has yet been submitted.

\section{The Yukon claim.}

The half-million-square-mile Yukon Territory contains only 22,000 people - but in contrast with the Northwest Territories, Europeans have long outnumbered the native people. No treaties had been made with the 3,240 Indians or the 1,200 Métis. In 1968 federal funding helped the Indian bands to form the Yukon Native Brotherhood, which was authorised to negotiate a settlement of Indian grievances. Over four years (with many meetings in native villages so real consensus could be reached) a claim was prepared, entitled 'Together today for our children tomorrow'. The claim, presented to the govermment in February 1973, aimed at enabling Indians 'to live and work together on equal terms with the white man'. The Council for Yukon Indians, representing status and non-status Indians, was then formed to negotiate with the government in a series of meetings lasting until February 1976, when the target date for an agreement-in-principle was postponed. Pressure for claim settlement intensified in 1976 when an alternative pipeline route through the Yukon was suggested to the Berger inquiry. In January 1977 the government's fulltime negotiator suggested a new 'co-operative planning' approach, under a Planning Council representing the Indians and the federal and territorial governments. Working groups produced reports on each topic for settlement, utilising public discussion and making use of external expertise to suggest all the options available. 51 In 1977 Kenneth Lysyk was appointed to conduct a four-month inquiry on the social and environmental impact of the proposed Alaska Highway pipeline and this produced a planning strategy which included Indian interests. But when the government put forward a settlement proposal based on the Planning Council work, the Council of Yukon Indians asked for more time to consult Indian communities. A year later, in January 1979 , they submitted a revised claim proposal. Intensive negotiations were interrupted by the new government's review, but resumed in November 1979. No final settlement has yet been reached.

\section{The problems of negotiating the future.}

The Canadian government is committed to maintaining its treaty obligations and settling outstanding native claims. The government acknowledges that 'the claims are not only for money and land, but involve the loss of a way of life'. But they want a 'just and final' settlement - as soon as possible. The decisions required are not easy for native people.

50 Watkins 1977; Berger 1977.

51 Naysmith 1977. 


\section{ABORIGINAL HISTORY 1988 12:1}

As Mary Bearskin of Fort George says, 'We are not thinking only of ourselves but of all those young kids who are just starting to hunt, and those that have yet to be born'.

The government genuinely wants the native claims settlements to provide a lasting solution to the cultural, social and economic problems of the Indians and Inuit. But it insists the settlements must also take into account the interests of all residents in the area covered. This of course is the political responsibility of a national government. The Canadian government has a special sensitivity about defending its overriding sovereignty in all areas of Canada, and will certainly oppose 'separatist' demands for exclusive political control of any region by a particular ethnic group. The Dene and Nunavut claims, which demand 'outright and exclusive control over the lands and resources in the entire area of traditional use', will not be easily negotiated.

The recent Canadian experience in negotiating 'comprehensive claim' settlements shows - if nothing else - that negotiation is more difficult than paternalism. But the Fourth World people will no longer allow administrators to decide their future for them. They will negotiate the future for themselves.

The negotiation process, if it is not hurried by pressure for resource development, potentially allows government representatives and native people to learn about the political realities of their respective positions. In the comprehensive claims Indians and Inuit are seeking settlements which redefine their position in Canadian society. The changes in law, political institutions and government programs which are necessary can come only from direct debate with the political decision-makers in the national government. 52

The earlier North American treaties, and the Treaty of Waitangi, also show the lasting value of negotiation. Long ago, in the Queen's name, honourable men pledged themselves, their people and their heirs to uphold the treaty agreements. They bound themselves to share territory and live in peace, to deal justly with one another for all time. The written promises endure, to reproach generations of greedy men. The treaties have outlasted changes in law, changes in policy, and changes in government. The courts uphold the pledged word of men long dead, insisting that their promises be redeemed, asserting that the tribes who gave up their heritage in return for the sovereign's protection will forever be entitled to justice. The treaties remind Maoris and Indians that their ancestors met the Queen's representatives as equals, offering property of great value in exchange for the promised rights. The treaties remind other citizens that these lands once belonged to others, that we owe our prosperity to their goodwill. Today, in the Queen's name, these national governments are making reparation for past injustices, are binding themselves and their successors to honour new agreements with the original owners of their territory.

The Aboriginal Treaty Committee has reminded other Australians that the Queen's representatives have never invited the Aborigines to negotiate their future. Nor have they acknowledged the Aborigines' moral right to compensation for the taking of their lands.

One of the most significant elements of Indian treaty law is that Indian treaties were not a grant of rights from the United States to the tribes, but rather a grant from the tribes to the United States.

American Indian Policy Review Commission

1977:95. 


\section{MAKING A TREATY}

\section{BIBLIOGRAPHY}

American Indian Policy Review Commission. Final Report. Washington DC, 1977.

Barber, L.I. Indian land claims and rights. Speech for symposium on Amerindians, The Royal Society of Canada, October 1974.

Berger, Justice Thomas R. Northern frontier, northern homeland, vol.1. Ottawa, 1977.

Brown, George and Ron Maguire. Indian treaties in historical perspective. Ottawa, 1979.

Canada Indian Claims Commission. Indian claims in Canada. Ottawa, 1975.

Cardinal, Harold. The unjust society. Edmonton, 1969.

The rebirth of Canada's Indians. Edmonton, 1977.

Chrétien, Jean, Statement made by the Honourable Jean Chrétian, Minister of Indian Affairs and Northern Development, on claims of Indian and Inuit people, 8 August 1973. Department of Indian and Northern Affairs, Communiqué, 1973.

Cohen, Felix S. "The Spanish origin of Indian rights in the law of the United States', in L.K. Cohen ed., The legal conscience, pp.230-52. New Haven, Conn., 1960a.

Cohen, Felix S. 'Indian claims', in L.K. Cohen ed., The legal conscience, pp.264-72. New Haven, Conn. 1960b.

Cohen, Felix S. 'Original Indian title', in L.K. Cohen ed., The legal conscience, pp.273-304. $1960 \mathrm{c}$.

Coombs, H.C. Aboriginal land rights teach-in. Canberra, 1979a.

The proposal for a treaty between the Commonwealth and Aboriginal Australians. Canberra, 1979b.

Cumming, Peter A. 'Native rights and law in an age of protest', Alberta Law Review 11 , 1973:238-59.

'Native land rights and northern development', Alberta Law Review 12, 1974:57-68.

and Neil H. Mickenberg. Native right in Canada. Toronto, 1972.

Daniel, Richard C. A history of native claims processes in Canada 1867-1979. Ottawa, 1980.

Department of Indian and Northern Affairs, Canada. Communiqués. Ottawa, 1977.

Frideres, J.S. Canada's Indians: contemporary conflicts. Scarborough, 1974.

Fumoleau, René. As long as this land shall last. Toronto, 1975.

Green, L.C. 1970 'Canada's Indians; federal policy, international and constitutional law', Ottawa Law Review 4:101-31.

Trusteeship and Canada's Indians', Dalhousie Law Journal 3, 1979-77:104-35.

Hagan, William T. The reservation policy: too little and too late', in J.F. Smith and R.M. Kvasnicka eds, Indian-white relations, pp.257-69, Washington DC, 1976.

Harris, Stewart. 'It's coming yet . . An Aborinal treaty within Australia between Australians'. Canberra, 1979.

Hookey, John. "The Gove land rights case: a judicial dispensation for the taking of Aboriginal lands in Australia?', Federal Law Review 5, 1972:85-114.

Hunt, Constance D. 'Approaches to native land settlements and implications for northern land use and resource management policies', in R.F. Keith and J.B. Wright eds, Northern transitions, vol.2 Toronto, 1978.

Inuit Tapirisat of Canada (ITC). 'Nunavut', Inuit Today 4, 1975:26-31, 81. 'Inuit land claims', Inuit Today 5, 1976:26-33.

Jordan, Anthony. 'Government, two - Indians, one', Osgoode Hall Law Journal 16, 1978:70922.

Kawharu, I.H. Maori land tenure. Oxford, 1977.

King, Michael. Te Ao Hurihuri: the world moves on. Wellington, 1975.

LaRusic, Ignatius et al. Negotiating a way of life: initial Cree experience with the administrative structure arising from the James Bay Agreement. Ottawa, 1979.

Lester, Geoffrey and Graham Parker. 'Land rights: the Australian Aborigines have lost a legal battle, but . . . Alberta Law Review 11, 1973:189-237. 


\section{ABORIGINAL HISTORY 1988 12:1}

Lurie, Nancy O. 'The Indian Claims Commission Act', Annals of the American Academy of Political and Social Science 311, 1957:56-70.

Lysyk, Kenneth. 'The unique constitutional position of the Canadian Indin', Canadian Bar Review 45, 1967:513-53.

'The United States Indian Claims Commission', in P.A. Cumming and N.H. Mickenberg, Native rights in Canada. Toronto, 1972.

The Indian title question in Canada: an appraisal in the light of Calder', Canadian Bar Review 51, 1973a:450-80.

'Approaches to the settlement of Indian title claims: the Alaskan model', University of British Columbia Law Review 8, 1973b:321-42.

McConnell, W.H. The Calder case in historical perspective', Saskatchewan Law Review 38, 1973-74:88-122.

McNickle, D'Arcy. 'Commentary', in J.F. Smith and R.M. Kvasnicka eds, Indian-white relations. Washington DC, 1976.

Manuel, George and Michael Posluns. The fourth world: an Indian reality. Ontario, 1974.

Metge, Joan. The Maoris of New Zealand-Rautahi. London, 1976.

Mickenberg, Neil H. 'Aboriginal rights in Canada and the United States', Osgoode Hall Law Journal 9, 1971:119-56.

Morris, Alexander. The treaties of Canada with the Indians. Toronto, 1886. Facsimile edition 1971.

Narvey, Kenneth $M$. "The common law and native rights to land within the territory granted to the Hudson's Bay Company', Saskatchewan Law Review 38, 1973-74:123-233.

Naysmith, J.K. A statement to the Alaska Highway Pipeline Inquiry . . . 20 May, 1977. Indian and Northem Affairs, Canada, Communiqué, 1977.

Pearson, Ronald H. 'Native rights in the Northwest Territories - the caveat case', Alberta Law Review 12, 1974:278-90.

Richardson, Boyce. Strangers devour the land. Toronto, 1975.

'Smith, Derek G. ed. Canadian Indians and the law: selected documents 1663-1972. Toronto, 1975.

Stanner, W.E.H. White man got no dreaming. Canberra, 1979.

Washbum, Wilcomb E. 'The moral and legal justifications for dispossessing the Indians', in J.M. Smith ed., Seventeenth-century America. Chapel Hill, 1959.

Watkins, Mel ed. Dene Nation - the colony within. Toronto, 1977.

Weaver, Sally M. The hidden agenda: Indian policy and the Trudeau government. Toronto, 1980.

Wilkinson, Glen A. 'Indian tribal claims before the US Court of Claims', Georgetown Law Journal 55, 1966-67:511-28.

Witt, Shirley Hill. 'Nationalistic trends among American Indians', in S. Levine and N.O. Lurie eds, The American Indian today. Baltimore, 1968. 